\title{
Physicochemical and Nutritional Characteristics of Solar and Sun-dried Tomato Powder
}

\author{
Mavis Owureku-Asare ${ }^{1,2}$, Ibok Oduro ${ }^{1}$, Firibu K. Saalia ${ }^{3}$, Charles Tortoe ${ }^{4} \&$ R. P. Kingsly Ambrose ${ }^{2}$ \\ ${ }^{1}$ Department of Food Science and Technology, Kwame Nkrumah University of Science and Technology, Kumasi, \\ Ghana \\ ${ }^{2}$ Department of Agricultural and Biological Engineering, Purdue University, West Lafayette, Indiana, USA \\ ${ }^{3}$ School of Engineering, University of Ghana, Accra, Ghana \\ ${ }^{4}$ Food Research Institute, Council for Scientific and Industrial Research, Accra, Ghana \\ Correspondence: Mavis Owureku-Asare, Department of Food Science and Technology, Kwame Nkrumah \\ University of Science and Technology, private mail bag, Kumasi, Ghana. Tel: 233-264-646-016. E-mail: \\ mowureku.asare@gmail.com
}

Received: July 31, 2018

Accepted: August 17, $2018 \quad$ Online Published: September 10, 2018

doi:10.5539/jfr.v7n6p1

URL: https://doi.org/10.5539/jfr.v7n6p1

\begin{abstract}
Tomato (Solanum lycopersicum) is one of the most important vegetable plants in the world used in cooking foods. In Ghana, at peak seasons of harvesting tomato, high postharvest loses are incurred because of the absence of industrial tomato processing facilities for value addition into other convenient forms to extend shelf-life. Solar drying is a more efficient and low cost method of enhancing the quality and adding value to tomato. This study was carried out to design a natural mixed mode solar dryer suitable for drying tomato and to investigate the quality characteristics of the dried products. Fresh tomatoes were pre-treated with: a) $1 \%$ potassium metabisulfite solution; b) $1 \%$ ascorbic acid solution; and c) used untreated as control. Pre-treated tomatoes were dried for three days on the average till there was no significant change in the final moisture content. Open-sun drying was used as a control for comparison purposes. The final moisture content for pre-treated solar dried and sun-dried tomato was $14-15 \%$ and $19-22 \%$, respectively. The ash content was higher in the sun-dried samples compared to the solar dried samples, an indication of contamination with extraneous materials from the environment. Sulfur dioxide content of $740.8 \mathrm{mg} / \mathrm{Kg}$ d.w., for solar dried tomato pre-treated with potassium metabisulfite was much lower than the maximum legal limit of $2000 \mathrm{mg} / \mathrm{Kg}$ d.w., of sulfur dioxide recommended in fruits. Solar and sun-dried tomato pre-treated with potassium metabisulfite had significantly higher carotenoids, lycopene and beta carotene contents than pre-treated samples, and the controls. The quality of pre-treated solar-dried tomato was better enhanced by the use of the solar dryer compared to sun-drying.
\end{abstract}

Keywords: lycopene, post-harvest loses, pre-treatment, quality, solar drying tomato

\section{Introduction}

Ghana consumes about 25,000 tonnes of tomatoes per annum worth $\$ 25$ million and is currently ranked the world's second highest country in canned tomato importation (Aryeetey, 2006). These massive imports have negatively affected the livelihoods of tomato farmers. Improving domestic tomato processing would help to minimize the over dependence on canned tomato imports, offer employment opportunities to the youth (Owureku-Asare et al., 2013) and reduce the high post-harvest losses during the peak season as well as strengthen the tomato value chain. Processing technologies, such as drying, have the potential to help farmers preserve agricultural produce and distribute them to markets, even in other countries (Jon \& King, 2008). Drying is one of the oldest methods of food preservation. It is a relatively inexpensive technology and it preserves foods by removing enough moisture to prevent decay and spoilage by microorganisms. Sun drying is an effective method of preserving and maintaining the quality of fresh produce. It lowers the water activity of the produce and consequently reduces microbial activity. Sun drying however, is associated with safety and quality problems such as contamination with dust and other extraneous materials, color degradation and poor rehydration characteristics. It is also associated with high microbial loads in the products due to slow drying rates of 
agricultural materials (Doymaz, 2004, 2005b). It has been established that the use of solar and hot-air dryers can significantly improve the safety and quality issues associated with sun-dried food products (Adom et al., 1997; Gogus \& Maskan, 1999; Doymaz \& Pala, 2002).

During the drying process, heated air initiates continuous physical and biochemical changes. The physical changes may result in changes in size, shape, color and texture whereas biochemical reactions cause oxidation of carotenoid and chlorophyll pigments, changes in the flavor, color and degradation of heat labile and UV sensitive nutrients in the produce (Lenart, 1996; Lin et al., 1998). Handling and preparation procedures prior to processing also cause substantial variation in nutrient loss (Gallali et al., 2000) and other physical properties of the dehydrated product. Some fruits and vegetables are pre-treated with different agents including calcium chloride, sulfur dioxide, ascorbic acid, vinegar, etc before drying to preserve certain vitamins, maintain color, reduce microbial contamination and prevent storage changes (Prabhakar, 2014).

Gaseous sulfur dioxide, sodium or potassium bisulfite and metabisulfite are commonly used for pre-treating some fruits and vegetables during processing. This process known as sulfiting, protects the product against non-enzymatic browning during drying and storage (Ngoddy \& Ihekoronye, 1985). lycopene content of dried tomato was enhanced when tomato slices were pre-treatment with sodium metabisulfite solution before convection drying (Owureku-Asare et al., 2014). Potassium metabisulfite was used pre-treatment of tomato slices prior to drying significantly affected rehydration ratio, yeast count and color because sulfite plasmolysed the cells which facilitated the drying process (Gould \& Russel, 1991). However, due to health concerns over the use of sodium, potassium metabisulfite is a better substitute for pre-treating tomato.

Central to the drying operations is the need to maintain the quality and functionality of dehydrated food materials (Prabhakar, 2014). Assessment of dried tomato involves evaluation of sensory, microbial load, physical characteristics, nutritional parameters, as well as microstructural and rehydration characteristics (Ranganna, 1986; Gallali, Abujnah \& Bannani, 1999). Consequently, the quality of dried products is often used to assess the performance and efficiency of the dryer system (Chen et al., 2005). During the drying process, agricultural fresh produce undergoes continuous physical and biochemical changes. Typical physical changes of dried food product may result in changes in size, shape, color and texture whereas the biochemical reactions cause changes in the flavor, color and nutrients of perishable produce like tomato (Lin et al., 1998; Lenart, 1996).

The heated air used in the drying process initiates changes in the nutritional and chemical properties of tomato by causing oxidation of carotenoid and chlorophyll pigments. Stability of phytochemicals (such as lycopene and carotene) should be investigated because there is increasing awareness and interest in the health benefits it's stability during food processing should be investigated (Tonucci et al., 1995).

The aim of this study was to assess the physicochemical, nutritional quality characteristics of pre-treated solar dried tomato powder, processed using a mixed mode solar dryer.

\section{Materials and Methods}

\subsection{Sample Preparation}

Fresh tomato (Roma variety) was purchased from a farmer and transported in wooden crates at ambient temperature to the laboratory, where it was stored in an air-condition room at $16{ }^{\circ} \mathrm{C}$. Ripe but firm tomato was selected, washed under running tap water and then with $1 \%$ sodium metabisulfite solution. The tomato was cut into slices of $5 \mathrm{~mm}$, using tomato slicer (Jaccard stainless steel mandolin, USA). This size was selected based on results from preliminary studies (unpublished data). The initial moisture content of tomato was determined using the air-oven method (AOAC, 2000).

\subsection{Pre-treatments Prior to Dehydration Process}

The tomato slices were divided into three equal portions of $4 \mathrm{~kg}$ each and randomly assigned to three pre-process treatments as follows: dipping in (a) a solution of $1 \%$ Potassium metabisulfite (KMS) for $10 \mathrm{~min}$, (b) $1 \%$ ascorbic acid solution for $10 \mathrm{~min}$ and (c) untreated as control. The choice of these selected pre-treatment was based on preliminary studies carried out prior to this study.

\subsection{Dehydration Processes}

Drying experiments were performed in a mixed-mode natural convection solar dryer (MNCSD) (Figure 1a \& b) designed for tomatoes. The MNCSD was constructed by the Engineering Unit, Food Technology Research Division of the CSIR- Food Research Institute, Accra. The dimensions of the dryer chamber were length $(1.0 \mathrm{~m})$, width $(0.6 \mathrm{~m})$ and height $(1 \mathrm{~m})$ with a collector tilt angle of $15.6^{\circ}$ placed in a South North position for optimum solar radiation in Accra, Ghana which is located at $49 \mathrm{~m}$ above sea above sea level at $5.6301 \mathrm{~N} 0.1801 \mathrm{~W}$ 
(accuracy: $3 \mathrm{~m}$ radius, device info: Garmin eTrex 30). Pre-treated tomato slices $(4 \mathrm{~kg})$ were uniformly spread on rectangular mesh trays $(87 \mathrm{~cm} \times 53 \mathrm{~cm})$ and placed in the drying chamber of the solar dryer over three-day period till moisture content of 13-14\%. In order to compare the performance of the cabinet dryer with that of open sun drying, $4 \mathrm{~kg}$ of sliced tomatoes were placed on drying trays and sun-dried (Figure 2). Triplicate sun drying experiments were carried out alongside the solar dryer.

After drying, both sundried and solar dried tomato samples were milled separately into powder using Kenwood dry mill blender (BL335, United Kingdom) at 450W speed for $3 \mathrm{~min}$.

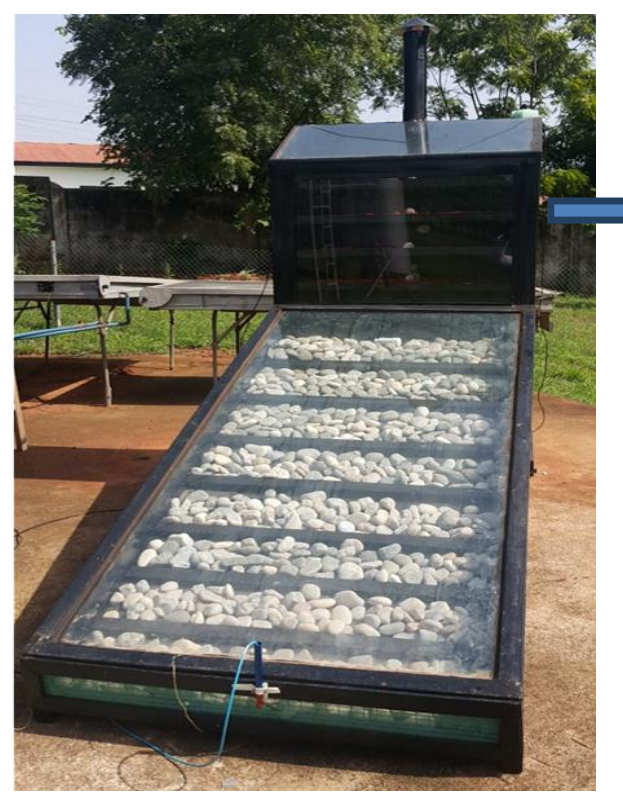

a.

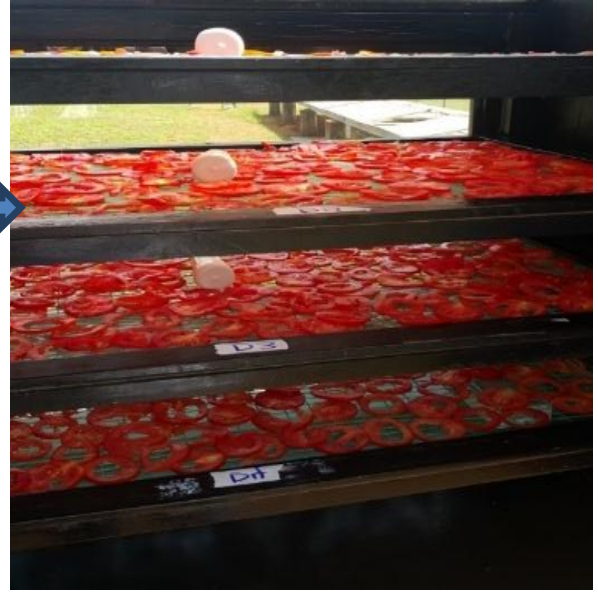

b.

Figure 1a \& 1b. Solar cabinet dryer

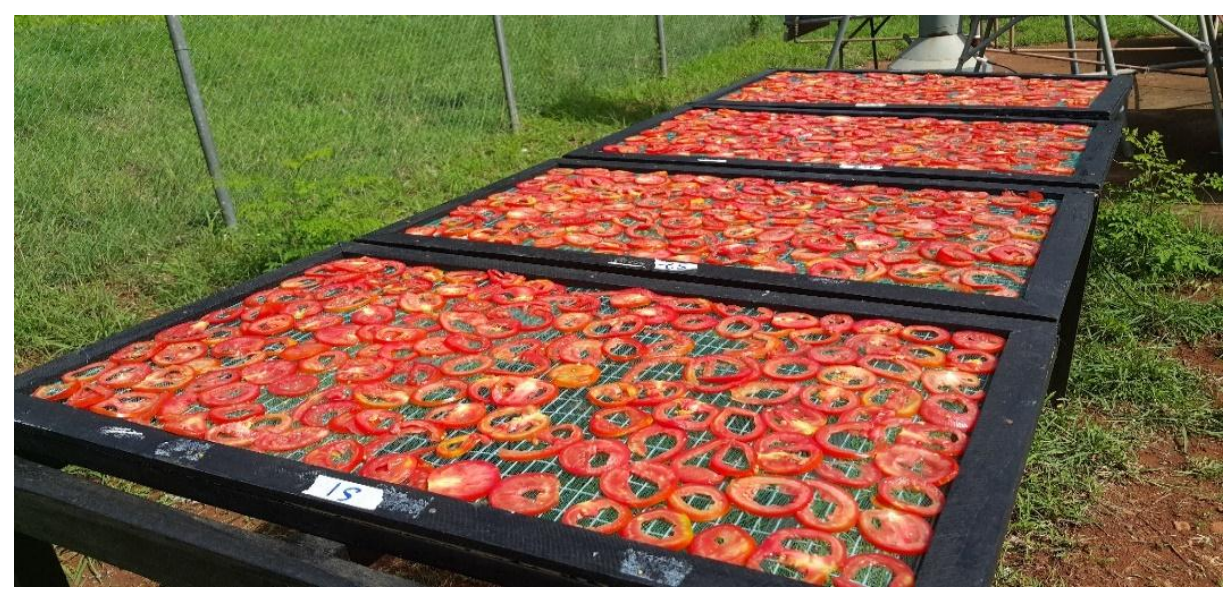

Figure 2. Sliced tomatoes on drying racks in open sun drying.

\subsection{Experimental Design}

A $3 \times 2$ factorial for pretreatment (1\% ascorbic acid solution, $1 \%$ metabisulfite solution and no pretreatment) and drying methods (solar and sun-drying) was used in the study. Tomato slices were subjected to three different pre-treatments (dipping in $1 \%$ potassium metabisulfite for $10 \mathrm{~min}$, dipping in $1 \%$ ascorbic acid for $10 \mathrm{~min}$, or using it as control without any pre-treatment). Each of the three samples was then dried under two drying conditions; solar and sun drying over a period of three days. Moisture content of samples was assessed at $2 \mathrm{~h}$ interval throughout the drying period. Experiments were carried out in triplicates between 9:30 and 16:30 $\mathrm{h}$ on sunny days (using British Broadcasting Corporation (BBC) weather forecast) during December 2015 to March 2016. 


\subsection{Physicochemical Quality Analysis of Fresh and Dried Tomato}

Fresh tomato was blended in a waring blender to obtain tomato juice. Ten percent (10\%) tomato solution was also prepared from tomato powder by mixing $10 \mathrm{~g}$ of tomato powder with $100 \mathrm{ml}$ of deionized water. Tomato solution and tomato juice (from fresh tomato) were used for the following analysis.

\subsubsection{Moisture and Total Solids}

The average initial moisture content for both the fresh and dried tomato samples were determined by drying $3 \mathrm{~g}$ of samples in a convection oven at $105{ }^{\circ} \mathrm{C}$ for $10 \mathrm{~h}$ (AOAC, 2000). Total solids were estimated by subtracting moisture content from $100 \%$. Moisture content and total solids of fresh and dried tomato samples were determined in triplicates.

\subsubsection{Water activity $\left(\mathrm{a}_{\mathrm{w}}\right)$}

Water activity was determined using a water activity meter (Paw kit, Model Series 3 TE, Decagon Devices, Inc., Pullman, WA, USA) for fresh and dry tomato samples, respectively.

\subsubsection{Color}

Tristimulus color of the fresh tomato and dried tomato (tomato powder) samples were measured using the chroma meter (LABSCAN XE Hunterlab, VA, USA) and reported in CIELAB color scales. The $\mathrm{L}^{*}$ value being the degree of lightness to darkness, $a^{*}$ value the degree of redness to greenness, and $b^{*}$ value, is degree of yellowness to blueness. The chromameter was calibrated against a white tile $\left(\mathrm{L}^{*}=100\right)$. The total color difference $\Delta \mathrm{E}$ was calculated as:

$$
\Delta E^{*}=\sqrt{\Delta L^{* 2}+\Delta a^{* 2}+\Delta b^{* 2}}
$$

\subsubsection{Total Soluble Solids (TSS)}

Total Soluble Solids of tomato juice was measured in triplicate using a digital Refractometer (AR 200, Reichert Analytical instrument, NY, USA). TSS of tomato powder was determined by reconstituting tomato powder into $10 \%$ solution before placing a drop of the juice on the lens of the refractometer after which subsequent reading were taken.

\section{$2.5 .5 \mathrm{pH}$}

The $\mathrm{pH}$ of the tomato juice was determined using $\mathrm{pH}$ meter (Symphony SB70P VWR, Radnor, PA, USA). The $\mathrm{pH}$ of dried tomato was measured from $10 \%$ tomato solution made from tomato powder and determined with a $\mathrm{pH}$ meter. The $\mathrm{pH}$ readings were taken in triplicates for both fresh and dried tomato.

\subsubsection{Total Titratable Acidity}

Titratable acidity of fresh tomato and $10 \%$ was calculated as percentage citric acid according to method by Elfalleh 2011. Ten grams of tomato powder was mixed in 100ml of distilled water and filtered. Ten milliliters of the filtrate was titrated with a solution of $\mathrm{NaOH}(0.1 \mathrm{~N})$ till $\mathrm{pH}$ end point of $\mathrm{pH} 8.1$. The TTA was expressed as citric acid equivalent.

$$
\% \text { TTA } \frac{\text { Titre value } x \text { Normality } x \text { M.eq.wt of acid } \times 100}{\text { volume of sample }} \times 100
$$

Milli-equivalent weight of citric acid $=0.06404$

\subsubsection{Ash}

The AACC Method 08-01(American Association of Cereal Chemists, 2000) was used to determine the ash content of tomato powder. Approximately, 4 grams of sample was weighed accurately into a silica ashing crucible which had previously been ignited, cooled in a desiccator and weighed. The samples were incinerated in a muffle furnace until a light grey ash was obtained, cooled in a desiccator and weighed. Ash was calculated as follows:

$$
\% \mathrm{Ash}=\frac{\text { weight of crucible }+ \text { ash })- \text { weight of empty crucible } \times 100}{\text { weight of sample }}
$$

\subsubsection{Sulfur Dioxide}

Total sulfur dioxide content (ppm dry weight basis) was determined using the modified Reith Williams Method (FAO, 1986). Sulfur dioxide was determined by dispersing $25 \mathrm{~g}$ of tomato powder was dispersed in $20 \mathrm{~mL}$ of 
water and diluted with $25 \mathrm{~mL}$ of dilute sodium hydroxide. It was allowed to stand for $5 \mathrm{~min}$ and diluted with 10 $\mathrm{ml}$ sulfuric and allowed to stand for another $5 \mathrm{~min}$, and $1 \mathrm{ml}$ of starch indicator added. It was titrated with standard iodine solution to a permanent purple color.

\subsection{Phytochemical Analysis}

\subsubsection{Extraction of Carotenoids}

Using $0.5 \mathrm{~g}$ of the hydrated powered tomatoes, the samples were crushed in a crucible mortar with $1.0 \mathrm{~g}$ sodium bicarbonate and celite to neutralize organic acid release. Twenty (20) $\mathrm{mL}$ of extraction solution (acetone: petroleum ether $(0.1 \%$ BHT) 1:1) was added to each sample through a vacuum filter into a flask. The filtrate was quantitatively collected and the process repeated three times until the residue was devoid of color. Forty (40) $\mathrm{ml}$ of $40 \%$ potassium hydroxide in methanol $(\mathrm{w} / \mathrm{w})$ was added and placed on magnetic stirrer for 10 minutes at room temperature. Combined extract is transferred into a $250 \mathrm{~mL}$ separating funnel and washed with distilled water. Ten (10) $\mathrm{ml}$ of saturated $\mathrm{NaCl}$ was added to break emulsions. Aqueous layer was drained, and the petroleum ether layer was quantitatively collected into a $25 \mathrm{~mL}$ volumetric flask with a funnel plug made of glass cotton wool. Aliquot of extract was dried under nitrogen atmosphere and dissolved in $1 \mathrm{~mL}$ of methanol: Ethyl Acetate (1:1) for HPLC analysis.

\subsubsection{HPLC Conditions}

A water liquid chromatographic instrument consisting of a Model 626 Pump, 717 plus auto sampler and column heater) and a Model 2996 photodiode array detector was used. Operation and data processing were performed by Empower software. Separation of carotenoids was performed using a $\mathrm{YMC} \mathrm{C}_{30}, 250$ x $4.6 \mathrm{~mm}, 5 \mu \mathrm{m}$ pore size with gradient elution of (A) Ethyl Acetate, (B) Methyl tertiary butyl ether and (C) methanol, in which elution started with $20 \% \mathrm{~A}$ and $80 \% \mathrm{C}$, which changed to $40 \% \mathrm{~A}$ and $60 \% \mathrm{~B}$ in 2 min then to $100 \% \mathrm{~A}$ in 12 min and then $20 \% \mathrm{~A}$ and $80 \% \mathrm{C}$ in $13 \mathrm{~min}$ and stayed isocratic for $7 \mathrm{~min}$. The flow rate was $1.0 \mathrm{ml} / \mathrm{min}$ for $20 \mathrm{~min}$. PAD spectrum of carotenoids was displayed between 200 and $700 \mathrm{~nm}$. Peak identification was based on comparison of retention time and spectral characteristics of carotenoids standards.

\subsubsection{Microstructural Evaluation}

Dried tomato slices were fixed in $2.5 \%$ glutaraldehyde for one hour and rinsed in buffer for 5 min. It was immersed in $2 \%$ aqueous osmium tetroxide for $90 \mathrm{~min}$. Osmium was rinsed out with deionized water for 5 min. This was repeated three times. Samples were then dehydrated in ethanol (ETOH) series of $50 \%, 70 \%$ and $95 \%$ for $10 \mathrm{~min}$ each repeated three times. Specimen samples were placed in metal baskets, coded and processed in a critical point dryer and then mounted on carbon tape for sputter coating with platinum for $120 \mathrm{sec}$. The samples were imaged with an FEI Quanta 3D FEG scanning electron microscope (FEI Company, Hillsboro, OR) using

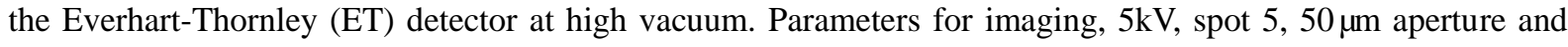
working distance of $\sim 10 \mathrm{~mm}$.

\subsubsection{Particle Size Analysis of Tomato Powder}

Tomato particle size and shape distribution was determined using a Morphologi G3-ID (Malvern Instrument, Malvern, United Kingdom). A total of 10,000 particles were analyzed to obtain the number distribution of circle equivalent (CE) diameter, convexity, and high sensitivity (HS) circularity. CE-diameter is the measurement of particle size, expressed as the diameter of a circle with the same area as the particle image. Convexity is the measurement of the surface roughness of a particle and it is calculated by dividing the convex hull perimeter by the actual particle perimeter. The value of convexity ranges from 0 to 1 . HS-circularity quantified how close the shape is to a perfect circle by the ratio of the particle area to the square of the perimeter of the object.

\subsection{Data Analysis}

All data were analyzed using Minitab version 7. Means and standard deviations of the data were presented. ANOVA and Duncan's multiple range test carried out to determine differences among treatments at the significant level of $p \leq .05$.

\section{Results and Discussion}

\subsection{Physicochemical Assessment of Tomato Powder}

The moisture content of fresh tomato was high at $94.73 \% \pm 0.43$ (Table 1) making tomato highly susceptible for spoilage. According to USDA database, lycopene content of fresh tomato ranges from $0.88-4.2 \mathrm{mg} / 100 \mathrm{~g}$ fresh weight, and b-carotene content lies slightly $(0.1-0.7 \mathrm{mg} / 100 \mathrm{~g}$ fresh weight) (http://www.nal.usda.gov/fnic/foodcom). The lycopene content of fresh roma tomato used in this study fell within this range (Table 1). 
Table 1. Physicochemical quality of fresh Roma tomato

\begin{tabular}{ll}
\hline Analysis & Fresh tomato \\
\hline Moisture $(\%)$ & $94.73 \pm 0.43$ \\
Dry matter $(\%)$ & $5.27 \pm 0.43$ \\
Ash dwb $(\mathrm{g} / 100 \mathrm{~g})$ & $8.50 \pm 0.78$ \\
Acidity $(\mathrm{g} / 100 \mathrm{~g})$ & $0.43 \pm 0.02$ \\
$\mathrm{pH}$ & $4.13 \pm 0.01$ \\
$\mathrm{~L}^{*}$ & $44.65 \pm 0.82$ \\
$\mathrm{a}^{*}$ & $22.71 \pm 1.34$ \\
$\mathrm{~b}^{*}$ & $14.50 \pm 2.38$ \\
Lycopene & $1.49 \mathrm{mg} / 100 \mathrm{~g}$ \\
Beta carotene & $0.55 \mathrm{mg} / \mathrm{g}$ \\
${ }^{\circ} \mathrm{Bx}$ & $4 \pm 0.0$ \\
$\mathrm{a}_{\mathrm{w}}$ & $0.99 \pm 0.01$ \\
\hline
\end{tabular}

\subsection{Effect of Pre-treatment and Drying Method on Physicochemical Parameters of Dried Tomato}

The moisture content of solar dried tomato powder ranged from $13.94 \pm 0.75 \%$ to $14.57 \pm 0.21 \%$ was observed whereas $19.38 \pm 0.36 \%$ to $21.63 \pm 2.36 \%$ for sundried tomato. The moisture content of solar dried tomato was significantly $(p \leq 0.05$ ) lower than sundried tomato (Table 2). The relative humidity of ambient air was consistently higher than that of the solar dryer during drying and as such moisture was readily absorbed by tomato at a faster rate from the surrounding ambient air than that of a more controlled environment created within the solar dryer. Dried tomato contains sugars and cellulose which has hygroscopic properties and high affinity to moisture, enables it to absorbs and hold unto moisture from its surrounding environment.

Table 2. Physicochemical Quality characteristics of solar and sundried pre-treated tomato powder

\begin{tabular}{|c|c|c|c|c|c|c|c|c|c|c|c|c|}
\hline $\begin{array}{l}\text { Drying } \\
\text { Method }\end{array}$ & $\begin{array}{l}\text { Pre } \\
\text { treatment }\end{array}$ & $\begin{array}{l}\text { Moisture } \\
(\%)\end{array}$ & Dry matter $(\%)$ & $\mathbf{a}_{\mathrm{w}}$ & $\begin{array}{l}\text { TTA } \\
(\mathrm{g} / \mathbf{1 0 0 g})\end{array}$ & pH & ${ }^{\circ} \mathbf{B} \mathbf{x}$ & $\begin{array}{l}\text { Ash } \\
(g / 100 g) d w\end{array}$ & $\mathbf{L}^{*}$ & $a^{*}$ & $\mathbf{b}^{*}$ & $\Delta \mathbf{E}$ \\
\hline \multirow{4}{*}{ Solar } & Control & $13.99^{\times \mathrm{A}}$ & $86.01^{\mathrm{yB}}$ & $0.37^{\mathrm{xA}}$ & $1.70^{\mathrm{xA}}$ & $4.16^{\mathrm{xA}}$ & $7.0^{\mathrm{yB}}$ & $9.68^{\mathrm{xA}}$ & $48.63^{\mathrm{xyB}}$ & $20.41^{\mathrm{yB}}$ & $30.26^{\mathrm{xB}}$ & - \\
\hline & KMS & $13.94^{\mathrm{xA}}$ & $86.06^{\mathrm{yB}}$ & $0.38^{\mathrm{xA}}$ & $2.87^{\mathrm{yB}}$ & $4.09^{\mathrm{xA}}$ & $6.0^{\mathrm{xA}}$ & $9.40^{\mathrm{xA}}$ & $50.35^{\mathrm{yB}}$ & $20.26^{\mathrm{yB}}$ & $31.76^{\mathrm{xB}}$ & $3.52^{\mathrm{xB}}$ \\
\hline & & $(0.75)$ & $(0.75)$ & $(0.05)$ & $(0.03)$ & $(0.08)$ & $(0.0)$ & $(0.91)$ & $(2.9)$ & (1.39) & $(1.88)$ & $(0.32)$ \\
\hline & $\mathbf{A A}$ & $14.57^{\mathrm{yA}}$ & $85.43^{\mathrm{xB}}$ & $0.35^{\mathrm{xA}}$ & $1.71^{\mathrm{xA}}$ & $4.07^{\mathrm{xA}}$ & $7.0^{\mathrm{yB}}$ & $9.55^{\mathrm{xA}}$ & $46.44^{\mathrm{xB}}$ & $20.38^{\mathrm{xAB}}$ & $28.87^{\mathrm{xB}}$ & $3.00^{\mathrm{yB}}$ \\
\hline \multirow[t]{5}{*}{ Sun } & Control & $19.38^{\mathrm{xB}}$ & $80.63 y^{A}$ & $0.53^{\mathrm{xB}}$ & $1.75^{\mathrm{xA}}$ & $4.16^{\mathrm{xA}}$ & $6.0^{\mathrm{xA}}$ & $9.30^{\mathrm{xA}}$ & $37.81^{\mathrm{xA}}$ & $20.91^{\mathrm{yB}}$ & $23.37^{\mathrm{XA}}$ & - \\
\hline & & $(0.36)$ & $(0.36)$ & $(0.02)$ & $(0.76)$ & $(0.01)$ & $(0.0)$ & $(0.15)$ & $(0.89)$ & $(0.72)$ & $(0.96)$ & \\
\hline & KMS & $21.36^{\mathrm{xyB}}$ & $78.64^{\mathrm{xyA}}$ & $0.56^{\mathrm{xB}}$ & $3.10^{\mathrm{yB}}$ & $4.08^{\mathrm{xA}}$ & $6.0^{\mathrm{xA}}$ & $10.03^{\mathrm{yB}}$ & $40.31^{\mathrm{yA}}$ & $17.13^{\mathrm{XA}}$ & $22.76^{\mathrm{XA}}$ & $2.93^{\mathrm{XA}}$ \\
\hline & & $(2.07)$ & (2.07) & $(0.04)$ & $(0.02)$ & $(0.09)$ & $(0.0)$ & $(2.02)$ & $(1.67)$ & $(2.00)$ & $(1.65)$ & $(0.14)$ \\
\hline & $\mathbf{A A}$ & $21.63^{\mathrm{yB}}$ & $78.3^{\mathrm{xA}}$ & $0.57^{\mathrm{xB}}$ & $1.79^{\mathrm{xA}}$ & $4.08^{x \mathrm{~A}}$ & $6.0^{\mathrm{xA}}$ & $10.18^{\mathrm{yAB}}$ & $41.48^{\mathrm{yA}}$ & $18.06^{\mathrm{XAB}}$ & $23.25^{\mathrm{xA}}$ & $2.55^{\mathrm{xA}}$ \\
\hline
\end{tabular}

Values are means of triplicate readings with a standard deviation in brackets.

Mean values in a column for pre-treatments with the same superscript $(x, y, z)$ are not significantly different $(p<0.05)$ from each other. Mean values in a column for drying method with the same superscript $(\mathrm{A}, \mathrm{B}$,$) are not significantly different (\mathrm{p}<0.05)$ from each other. Dw-On a dry weight basis.

TTA-Total titratable acidity

The moisture content of sundried samples fluctuated in response to the relative humidity of the ambient air. It was challenging reaching desirable low moisture content $(10-12 \%)$ for sun-dried samples compared to solar dryer which had elevated temperatures and lower final moisture content $(13.95 \pm 0.75 \%)$. Sun drying requires 7 to 12 days, and results in a product with typically $12 \%$ to $24 \%$ moisture and robust taste. (ECOM, 1997).

Water activity $\left(\mathrm{a}_{\mathrm{w}}\right)$ is a measure of how much of the water in a product is free and not chemically or physically bound, but which is available for food enzyme activity and microbial growth (Prabhakar et al., 2014). Water activity (aw) for solar dried tomato powder were significantly lower $(0.35 \pm 0.01$ to $0.38 \pm 0.05)$ than sundried tomato powder $(0.53 \pm 0.002$ to $0.57 \pm 0.03)$ (Table 2$)$. In a similar study by Rajkumar et al., (2007), significant differences were observed for $\mathrm{a}_{\mathrm{w}}$ of tomato slices dried in vacuum assisted solar dryers and open sun drying with corresponding moisture content of $11.5 \pm 0.01 \%$ (w.b). Pre-treatment of solar and sundried tomato powder did not have significant $(p>0.05)$ effect on water activity (Table 2$)$. In general, foods have $\mathrm{a}_{\mathrm{w}}$ levels in the range of 0.2 for very dry foods to 0.99 for moist fresh foods. Microorganisms can keep their viability regardless of the water activity, but growth bacteria require $a_{w}>0.8$ whiles yeasts and molds grow in $a_{w}>0.6$ (ECOM, 1997). 
Since dry fruits have $a_{w}$ of 0.4 ; thus the $a_{w}$ of solar dried tomato will enhance a stable storage shelf- life for the product. Water activity lower than 0.6 achieved was considered as microbiologically safe for storage (Wang \& Brennen, 1991).

Brix $\left({ }^{\circ} \mathrm{Bx}\right)$ of reconstituted solar dried tomato were significantly $(\mathrm{p} \leq .05)$ lower $(6.0)$ for all sundried samples (7.0), with the exception of KMS pre-treated solar dried tomato powder which was also 7.0 (Table 2). Generally, sun-dried tomato had lower brix than solar dried tomato. This could be due to the breakdown/fermentation of sugars observed from growth of yeast cells and characterized by off smell observed in sundried samples.

The $\mathrm{pH}$ ranged from $4.08 \pm 0.07$ to $4.16 \pm 0.01$ for sun dried and solar-dried tomato. There were no significant $(p$ $\leq 0.05$ ) differences in the $\mathrm{pH}$ for solar and sundried tomato powder. Total titratable acidity (citric acid) was significantly higher for solar $(2.87 \pm 0.03)$ and sun-dried $(3.10 \pm 0.02)$ tomato pre-treated with KMS than sample with other pre-treatments. KMS solution; an acidic solution releases sulfur dioxide gas during drying. The higher acidity recorded for sundried samples could be an indication of fermentation which occurred during sun drying.

The ash content was slightly higher in the sundried samples $(9.30-10.18 \%)$ compared to the solar dried tomato samples (9.4 - $9.68 \%$ ) (Table 2). Higher ash content is indicative of contamination by dust and other extraneous materials. In a study by Gallali et al., (2000) on dried grapes; significant differences in the ash content were observed for solar dried (2.95\%) and sun dried grapes $(12.1 \%)$ indicating higher fermentation associated with sun drying.

The $\mathrm{L}^{*}$ value for sundried tomato were significantly affected by the different pre-treatments. $\mathrm{L}^{*}$ color dried tomato pre-treated with ascorbic acid and KMS was higher than the control samples without any pre-treatment. The use of KMS and ascorbic acid which are both acidic in nature had a bleaching effect on the red color of tomato prior to drying. Significantly $(p<0.05)$ lower $L^{*}(37.81 \pm 0.89-40.31 \pm 1.67)$ observed in sundried dried tomato indicated that these samples were darker than solar dried samples higher $L^{*}$ values $(50.35 \pm 2.9$ $46.44 \pm 1.2$ ). Significant changes in $\mathrm{L}^{*}$ value for pre-treated solar dried tomato. In a similar study by Falade \& Shogaolu, (2010), higher $\mathrm{L}^{*}$ value was observed for sulfited pumpkin due to the bleaching effect of the sulfite treatment prior to air oven drying.

The presence of pigments susceptible to degradation by non-enzymatic and enzymatic reactions affects the color of fruits, and vegetables. A low $a_{w}$ in dry products leads to an increase in the half-life of the pigments (Pizzocaro et al., 1993). It was also observed that the color change in sun drying was mainly due to the non-enzymatic browning /Maillard reaction and it was in the solar dried samples compared to sun drying (Pizzocaro et al.,1993).

The color change of solar dried tomato pre-treated with KMS $(3.52 \pm 0.32)$ and ascorbic acid $(3.00 \pm 2.82)$ significantly differed from the control and was higher than pre-treated sundried tomato $(2.93 \pm 0.14-2.55 \pm$ 0.27). There was higher degradation of the red tomato color characterized by darker red color (brownish) in sundried tomato than solar dried. In a similar study by Latapi \& Barrett (2006), significant $(p \leq 0.05)$ differences were observed in the color of sundried tomato pre-treated with different concentrations of sodium metabisulfite. In that study color values $\left(\mathrm{Hue}^{\circ}\right)$ decreased with increasing concentration of sodium metabisulfite and a more desirable redder color was observed with increasing sodium metabisulfite concentration $(6-8 \%)$. Also Sun-dried tomatoes that were dipped in an $8 \%$ sodium metabisulfite solution had the highest sulfur dioxide content, and thus the best red color $\left(32.2 \mathrm{Hue}^{\circ}\right)$ compared with control sun-dried tomatoes with the highest hue angles before $\left(36.9 \mathrm{Hue}^{\circ}\right)$ and after storage (42.0 Hue) with darker brown color. During drying, pre-treatment with sulfur dioxide preserves color and reduces color degradation.

\subsection{Nutritional Assessment of Tomato Powder}

3.3.1 Effect of Pre-treatment and Drying Method on Beta Carotene, Lycopene and Total Carotenoid Quality of Tomato Powder

Table 4 shows the antioxidant composition of tomato powder. Tomato contains different kinds of micronutrients such as carotenoids, folate, vitamins (C and E), and phenolic compounds (Beecher, 1998; Periago \& Garcia-Alonso, 2009). Tomato is a rich source of lycopene, an important carotenoid which has enormous health benefits. Fresh tomato fruit contains about 7.2 to $200 \mathrm{mg}$ of lycopene per $\mathrm{kg}$ of fresh weight, which accounts for about $30 \%$ of the total carotenoids in plasma (Stahl \& Sies, 1996). In this study, fresh tomato contained 14.9 $\mathrm{mg} / \mathrm{of}$ lycopene per $\mathrm{kg}$ of fresh weight and the exocarp of fresh tomato contains about five times more lycopene than the pulp (Papaioannou \& Karabelas, 2012).

Solar-dried tomato pre-treated with KMS had significantly $(p \leq 0.05)$ high carotenoids $(43.13 \pm 1.43 \mathrm{mg} / 100 \mathrm{~g})$, lycopene $(50.35 \pm 2.01 \mathrm{mg} / 100 \mathrm{~g})$ and beta carotene $(29.16 \pm 0.78)$ compared with the other solar dried samples. Sun-dried tomato pre-treated with KMS also recorded significantly high $\beta$-carotene $(10.46 \pm 1.78 \mathrm{mg} / 100 \mathrm{~g})$, 
lycopene $(23.01 \pm 2.04 \mathrm{mg} / 100 \mathrm{~g})$ and total carotenoid concentrations $(33.21 \pm 0.76 \mathrm{mg} / 100 \mathrm{~g})$ compared with ascorbic acid pre-treated and control sun-dried samples (Table 4). Drying method significantly $(p \leq 0.05)$ affected the lycopene, $\beta$-carotene and total carotenoid levels in dried tomato samples. There was significant ( $p \leq$ 0.05 ) interaction of pre-treatment and drying method on the lycopene, $\beta$-carotene concentration which led to high values recorded for KMS pre-treated tomato. USDA database records lycopene of $45.90 \mathrm{mg} / 100 \mathrm{~g}$ and $\beta$-carotene of $0.524 \mathrm{mg} / 100 \mathrm{~g}$ on dry weight basis for sundried tomato (<http://www.nal.usda.gov/fnic/foodcomp >).

Processing such as drying can affect isomerization, bio-accessibility and concentration of lycopene (Knockaert et al., 2012). In a study carried out by Georgé et al., (2010), the thermal processing of tomato juice to puree, (at $92^{\circ}$ $\mathrm{C}$ for 10min) significantly $(p \leq 0.05)$ reduced total polyphenolic and vitamin $\mathrm{C}$ content in both yellow and red varieties, but did not significantly $(p \leq .05)$ lower the carotenoid content of red tomato. Freeze drying of tomato juice also reduced the carotenoid content but did not affect total polyphenol content of tomato. In a related study by Owureku-Asare et al., (2014), the lycopene content of conventional oven dried tomato pre-treated with sodium metabisulfite was $93.0 \pm 168 \mathrm{mg} / 100 \mathrm{~g}$ showing a lowering in degradation compared to samples pre-treated with ascorbic acid. This could be as a result of the protective effect of the metabisulfite. Sun drying, causes considerable carotenoid destruction whiles drying in a solar dryer reduces the exposure to direct sunlight. The destruction of carotenoids in tomato pre-treatment with antioxidant and sulphating agents reduces carotenoid degradation and inhibit the enzyme polyphenol oxidase, demobilizing it (Pizzocaro et al., 1999). In a study by Davoodi et al., 2007, the retarding effect of $\mathrm{CaCl}_{2}$ for browning and protective effect of KMS on lycopene was observed in tomato powders. All the carotenoids assessed were highest in KMS treated sun and solar dried tomato samples.

Table 4. Beta carotene, Lycopene and total carotenoid content of tomato powder

\begin{tabular}{lllll}
\hline Drying Method & Pre-treatment & $\begin{array}{l}\boldsymbol{\beta} \text {-carotene } \\
\mathbf{m g} / \mathbf{1 0 0 g}(\mathbf{d w})\end{array}$ & $\begin{array}{l}\text { Lycopene / } \\
\mathbf{m g} / \mathbf{1 0 0 g}(\mathbf{d w})\end{array}$ & $\begin{array}{l}\text { Total carotenoid } \\
/ \mathbf{m g} / \mathbf{1 0 0 g}(\mathbf{d w})\end{array}$ \\
\hline Solar & Control & $28.34^{\mathrm{zB}}(0.23)$ & $15.32^{\mathrm{yB}}(1.53)$ & $31.80^{\mathrm{zB}}(2.01)$ \\
& KMS & $29.16^{\mathrm{BB}}(0.78)$ & $50.35^{\mathrm{ZB}}(2.01)$ & $43.13^{\mathrm{zB}}(1.43)$ \\
\multirow{4}{*}{ Sun } & AA & $8.753^{\mathrm{xyA}}(0.94)$ & $2.69^{\mathrm{xA}}(1.82)$ & $9.02^{\mathrm{xA}}(0.92)$ \\
& Control & $9.86^{\mathrm{yA}}(1.09)$ & $13.86^{\mathrm{yA}}(0.24)$ & $28.54^{\mathrm{yA}}(1.72)$ \\
& KMS & $10.46^{\mathrm{yA}}(1.78)$ & $23.01^{\mathrm{yA}}(2.04)$ & $33.21^{\mathrm{B}}(0.76)$ \\
& AA & $6.39^{\mathrm{xA}}(1.39)$ & $11.25^{\mathrm{xA}}(0.34)$ & $15.21^{\mathrm{xA}}(0.78)$ \\
\hline
\end{tabular}

Values are means of triplicate readings with a standard deviation in brackets. Mean values in a column for pre-treatments with the same superscript $(x, y, z)$ are not significantly different $(p \leq .05)$ from each other. Mean values in a column for drying method with the same superscript $(A, B)$ are not significantly different $(p \leq .05)$ from each other. $d w$-dry weight.

\subsubsection{Particle Size and Shape Distribution of Tomato Powder}

\subsubsection{Size Diameter of Tomato Powders}

The physical properties including moisture content and milling methods affect particle size distribution of flours and powders (Gaines, 1985; Dexter et al., 1994). Sun-dried and solar dried tomato samples pre-treated with ascorbic acid and sundried control recorded higher percentage of particles with circle equivalent diameter (CE) of $2-10 \mu \mathrm{m}$ (Figure 1). The KMS pre-treated dried tomato powder had highest proportions of small particles between 2-5 $\mu \mathrm{m}$, there were also high volumes of particles ranging from $2-31 \mu \mathrm{m}$ making the particle larger than the rest of the powders. Sun dried tomato powder pre-treated with potassium metabisulfite and solar dried controlled samples also had relatively higher particle size between 2 - $14 \mu \mathrm{m}$. 


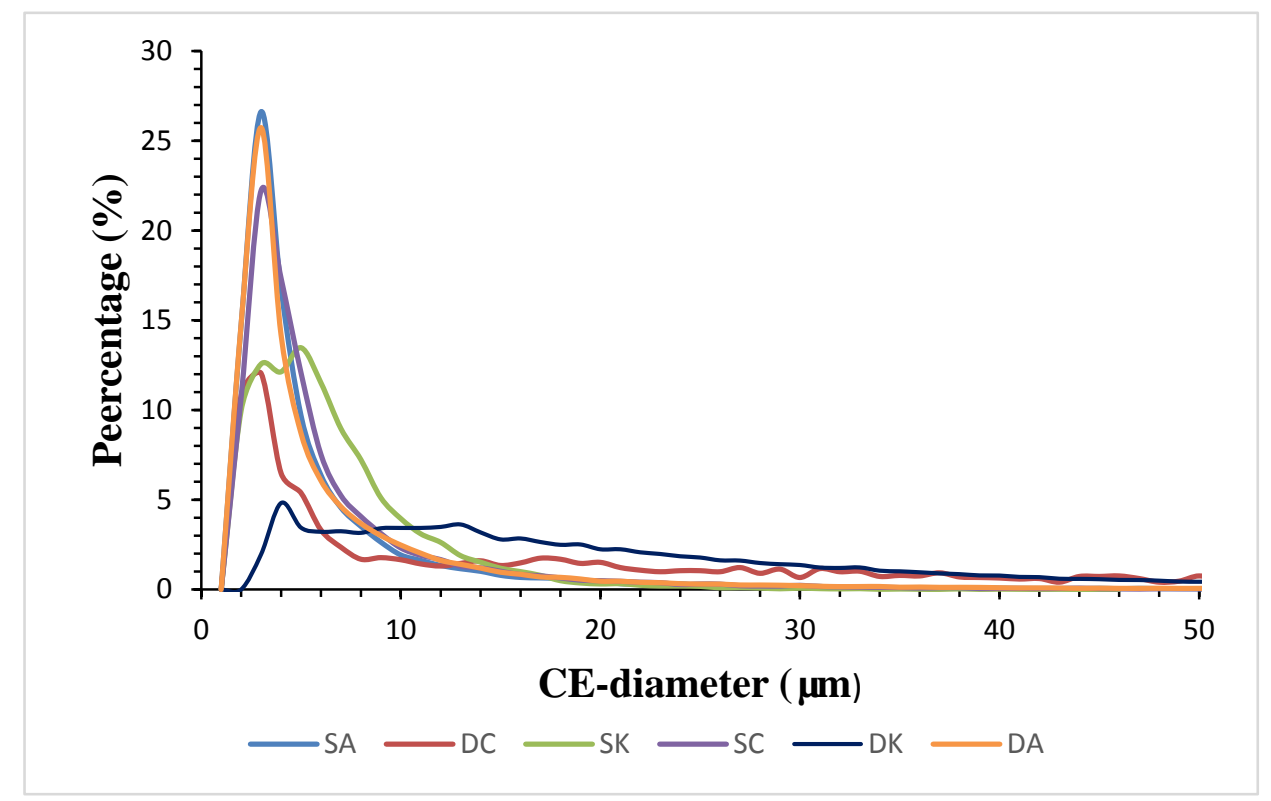

Figure 1. Distribution of tomato powder particle circle-equivalent (CE) diameter

SA- sundried tomato powder pre-treated with ascorbic acid; SK- sundried tomato powder pre-treated with potassium metabisulfite; SC-sundried tomato powder with no pre-treatment; DA- solar dried tomato powder pre-treated with Ascorbic acid; DK- solar dried tomato powder pre-treated with potassium metabisulfite; DCsolar dried tomato powder with no pre-treatment

In a study by Sign et al., 2005, the particles of blanched tomato powder were finer compared with un-blanched tomato powder. Blanched tomato hard a narrow range of particle sizes depicting more stable particles which is desirable in processing into other tomato products. Solar dried tomato powder pre-treated wit KMS (DK) had CE-diameter which was widely distributed compared to all other samples. SC, DA, SA, SK and DC had higher proportions (peak) of particles with size of up to $3 \mu$ while DK was $4 \mu$. Tomato powder mainly composed of sugars, mineral composition, organic acids, lycopene and total phenols (Verma et al., 2016). Compared to flours/powders from starchy foods, the dried skin/exocarp of the tomato gave the powder a chaffy and coarse texture with, the mesocarp of tomato producing a finer matrix to the powder. The narrow peaks for almost all the samples shows a larger proportion of smaller particles $(5-10 \mu \mathrm{m})$, an indication that the milling intensity increased damage of the sugars, resulting in sugars of smaller particle sizes (Verma et al., 2016). In a study of sorghum flour, the particles had diameters that ranged between 5 and $30 \mu \mathrm{m}$ (Choi et al., 2008), which suggests starch damage enhanced by the grinding process. 


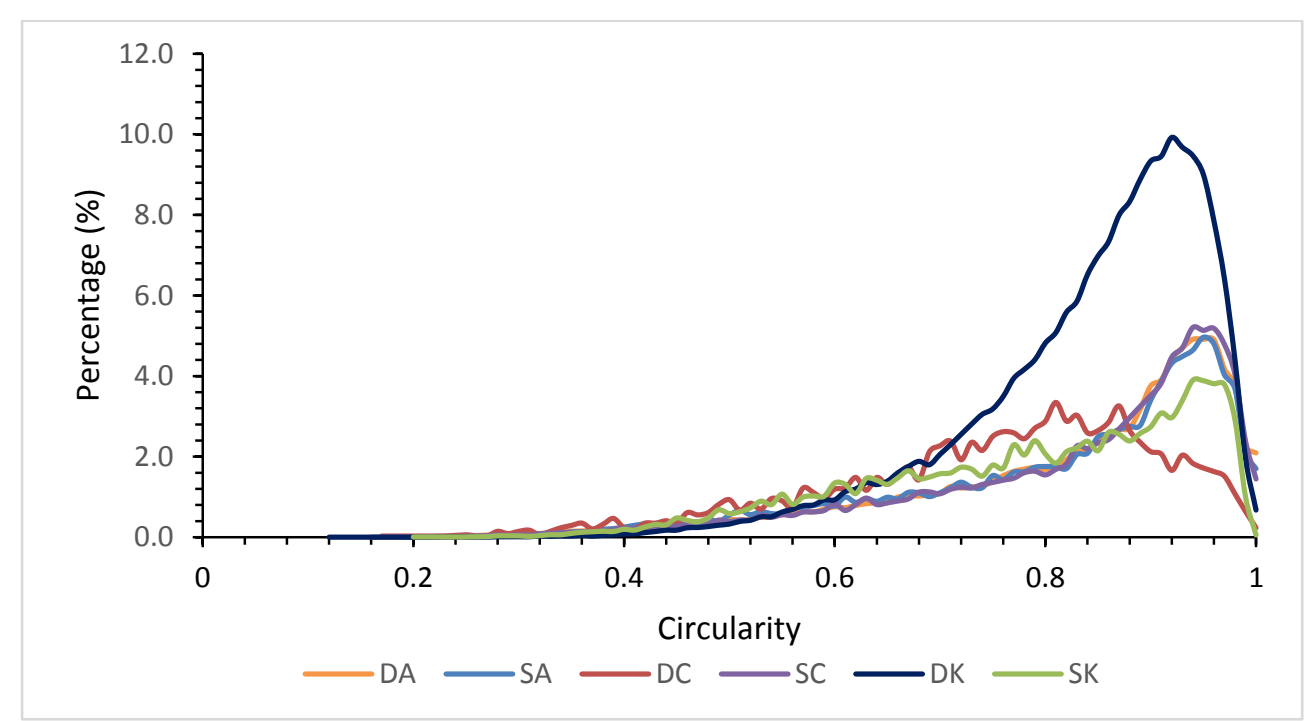

Figure 2. Distribution of tomato powder particle high-sensitivity (HS) circularity

SA- sundried tomato powder pre-treated with Ascorbic acid; SK- sundried tomato powder pre-treated with potassium metabisulfite; SC-sundried tomato powder with no pre-treatment; DA- solar dried tomato powder pre-treated with Ascorbic acid; DK- solar dried tomato powder pre-treated with potassium metabisulfite; DCsolar dried tomato powder with no pre-treatment

Even with the same milling process, the HS-circularity (Figure 2) and convexity (Figure 3) of tomato powder were highly different. The circularity of $10 \%$ of the particles of solar dried tomato powder pre-treated with KMS were $0.92 \%$ making up the highest proportion of the shape of the samples. The convexity of tomato powder granules was higher $(0.98-1.0)$ because most of the powder particles were separate and less shape-distorted. On the other hand, exocarp of tomato fractions had less uniform shapes, with low convexity and circularity similar to the bran of cereal flours (Saad et al., 2011). The KMS pre-treated solar dried tomato powder resulted in powder particles with more convex and circular shape compared to the other samples. The treatments with KMS could have weakened the bond between exocarp and mesocarp of tomato as well as between sugars, acids and protein, resulting in a better separation of powder particles. Figure 6 shows some particles of tomato powder. Different particle sizes had varied convexity and circularity and particles fractions that were mostly irregular, elongated and fibrous in shape seem to come from the exocarp of the tomato whiles others were mostly rounded were produced from the mesocarp matrix. From the results, it can be deduced that solar dried tomato pre-treated with KMS would give a smoother texture compared to the other samples when reconstituted into other tomato products. 


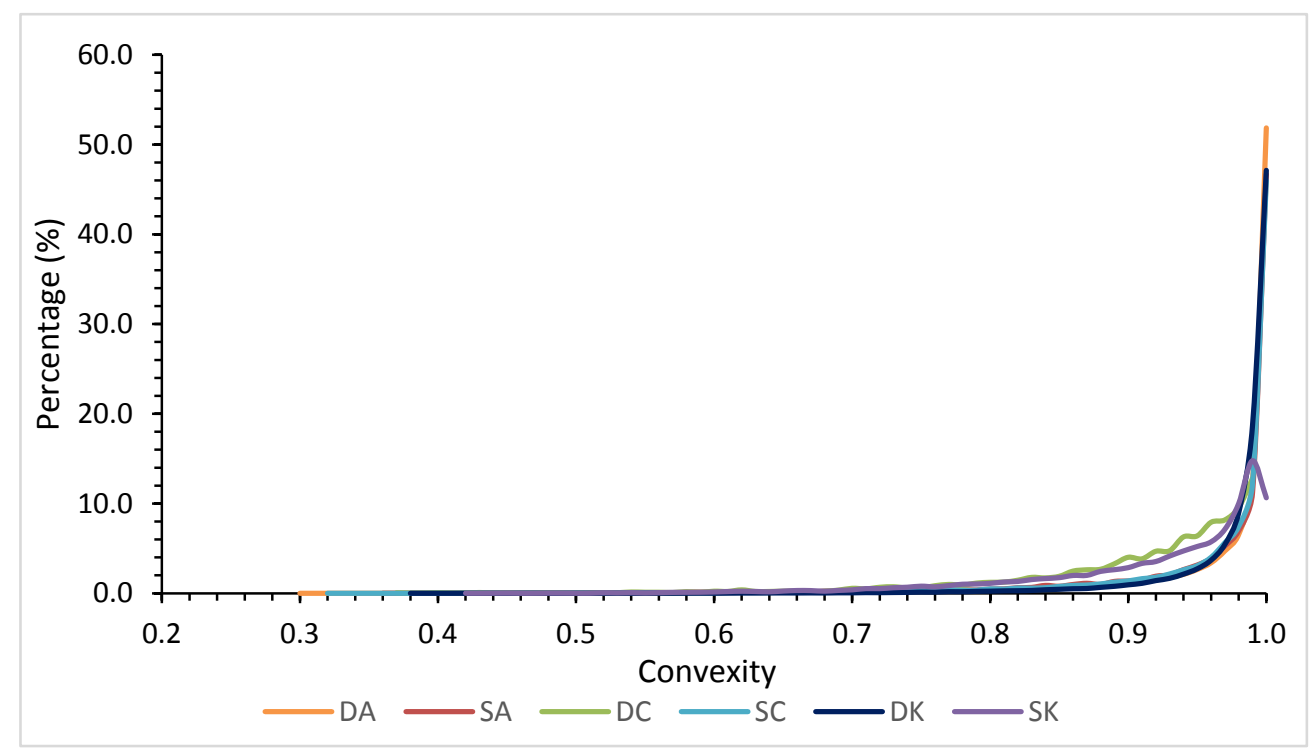

Figure 3. Distribution of convexity of tomato powder particles

SA- sundried tomato powder pre-treated with Ascorbic acid; SK- sundried tomato powder pre-treated with potassium metabisulfite; SC-sundried tomato powder with no pre-treatment; DA- solar dried tomato powder pre-treated with Ascorbic acid; DK- solar dried tomato powder pre-treated with potassium metabisulfite; DCsolar dried tomato powder with no pre-treatment

\subsection{Microstructural Evaluation of Dried Tomato}

Scanning electron microscopy uses microscopic techniques to examine the changes in the size and shape of the intercellular and cellular spaces and structural changes that occur when food is processed (Aguilera \& Lillford, 1996; Alzamora et al., 1996). The cellular structure of tomato influences the mode of transfer of nutrients and water during drying and this has an impact on the quality of dried tomato (Gekas, 1992).

The physical characteristics of foods correlates well with their microscopic structure (Tortoe \& Orchard, 2006). SEM of fresh tomato has rigid cell wells with firm edges and that of dried tomato looks depressed, distorted and deformed. Differences in the distortion, shape and appearance of cell walls could be observed for sun and solar dried samples (Figures 4 \& 5).

The Depressions are a sign of water loss. The depressions observed for the solar dried tomato are more pronounced at the cellular level compared to the sun dried (final moisture content $19-20 \%$ ); an indication of higher water loss in solar dried tomato (final moisture content 14 - $15 \%$ ).

Zogzas et al., (1994) explained the extent of collapse of the cell wall during drying as being proportional to the quantity of water lost during the drying process. This is similar to what was observed in a study by Owureku-Asare et al., (2014), about the structure of oven dried tomato.

From this observation, pre-treatment did not seem to affect the cell structure of solar and sun dried tomato as there were no visual differences observed in the cellular structures for the different pretreated samples. In similar studies by Sargent, 1998; Tortoe \& Orchard, 2006, for apple and banana respectively, osmotic dehydration caused the movement of water and deformation of the pectin, hemi cellulose and cellulose of the cell structure plasma membrane and middle lamella resulting in the collapse of the cell and plasmolysed cells.

Dried tomato is considered to be hygroscopic (Hawlader et al., 1991) and reconstitute well when water is added to it. The water moves freely across the gradient and is absorbed by the cellular membranes of tomato. 


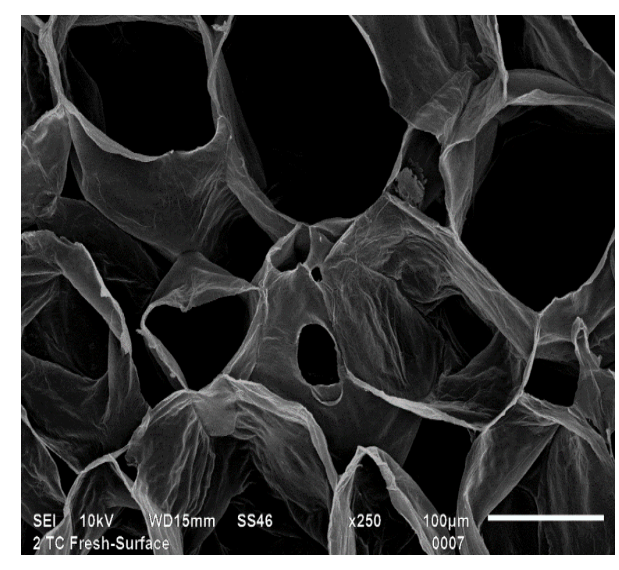

a)

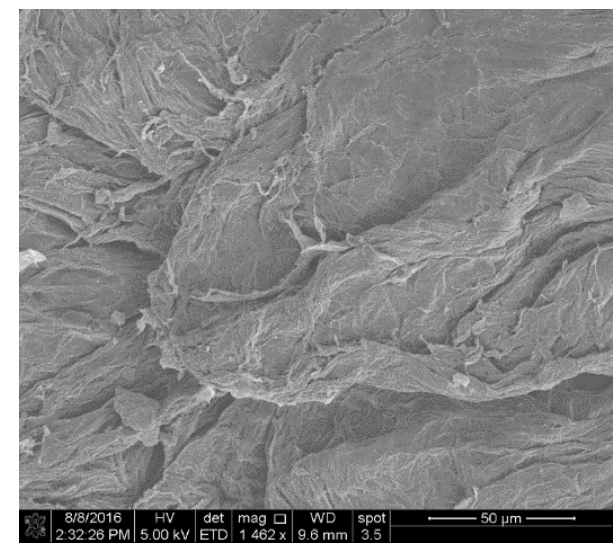

c)

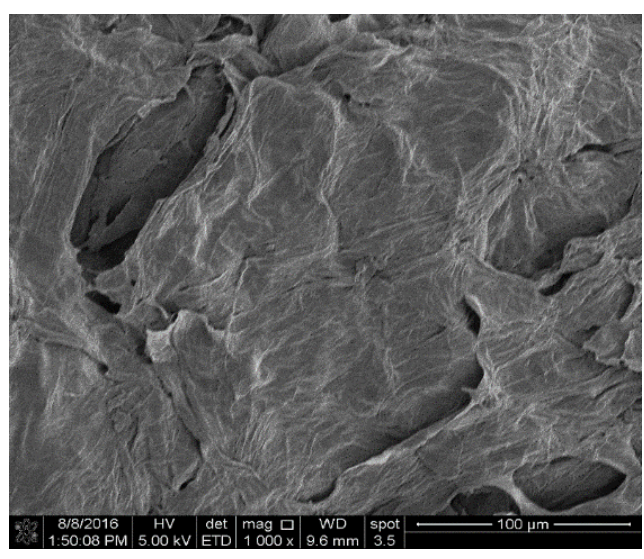

b)

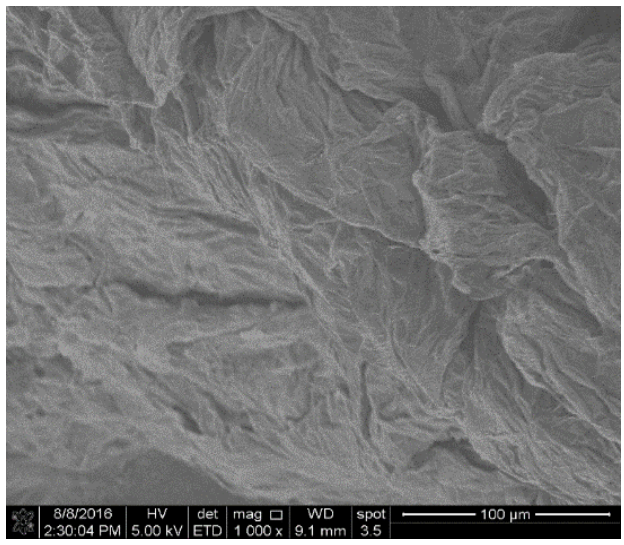

d)

Figure 4. The microstructure of the surface of (a) fresh tomato (b) sun-dried tomato slices with no pre-treatment (c) sun-dried tomato slice pre-treated with ascorbic acid (d) sun-dried tomato pre-treated with KMS at SEM magnification of 250, 100,50 and 100x respectively
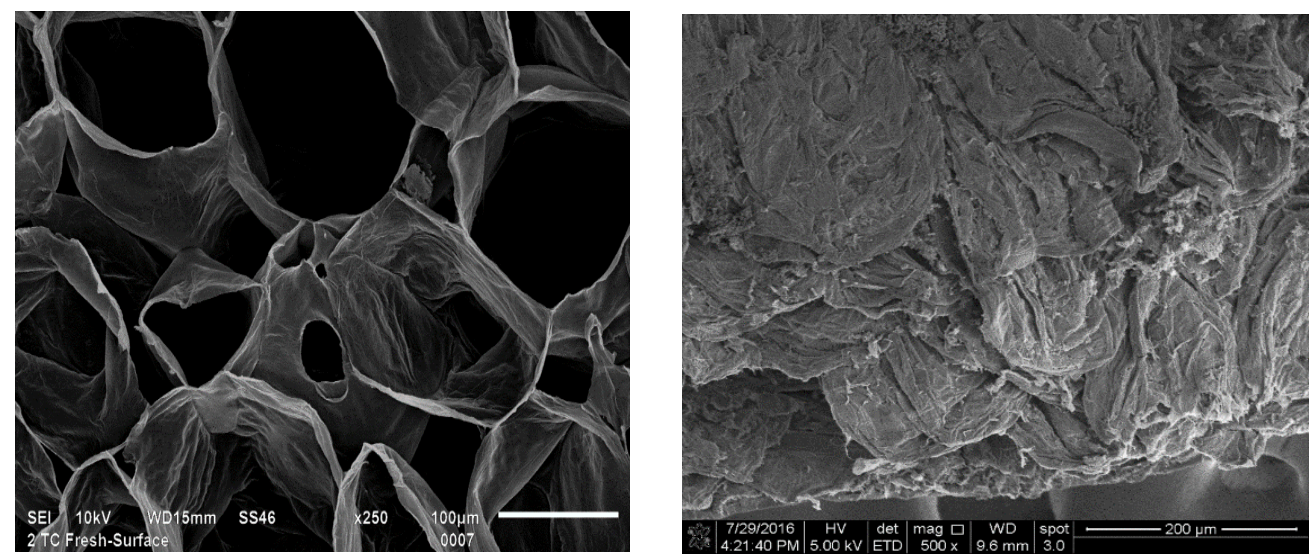

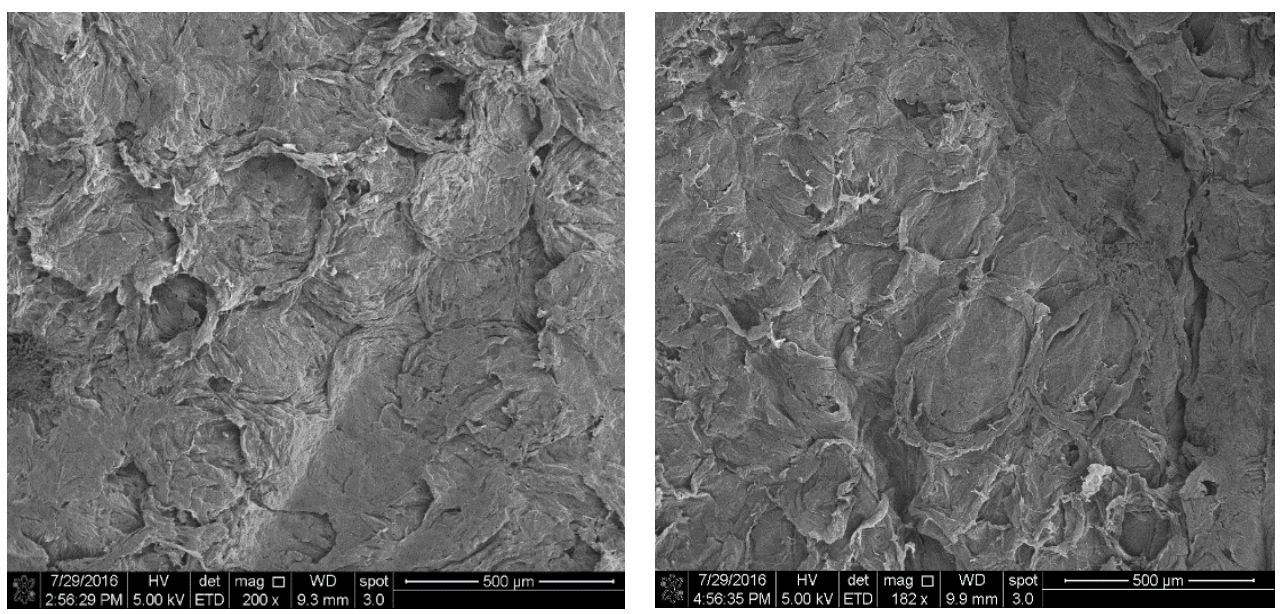

Figure 5. The microstructure of the surface of (a) fresh tomato (b) solar-dried tomato slices with no pretreatment (c) solar-dried tomato slice pretreated with ascorbic acid (d) solar-dried tomato pretreated with KMS at SEM magnification of 100,200,500 and 500x respectively

\section{Conclusion}

The ash content was higher in the sun-dried samples compared to the solar dried tomato samples, an indication of contamination with extraneous materials from the environment. Sulfur dioxide content of $740 \mathrm{mg} / \mathrm{Kg} \mathrm{d} . \mathrm{w}$. recorded for solar dried tomato pre-treated with potassium metabisulfite was much lower than the maximum legal limit of $2000 \mathrm{mg} / \mathrm{kg}$ d.w. sulfur dioxide recommended in fruits. Solar and sun-dried tomato pre-treated with potassium metabisulfite had significantly high carotenoids, lycopene and beta carotene compared with the other pre-treated samples and controls. Potassium metabisulfite pre-treated solar dried tomato powder particles were more convex and circular in shape compared to the other samples which enhances the reconstitution characteristics of tomato powder; an ideal quality for further processing into other products such as sauce or paste. Processing tomato paste locally by could help reduce huge imports of tomato paste. This dryer which is easy to operate and has the potential of helping to add value to tomato and reduce post-harvest losses incurred along the production and marketing chain.

\section{Acknowledgement}

This work was facilitated by financial and logistical support from The Norman E. Borlaug Leadership Enhancement in Agriculture Program (Borlaug LEAP), Department of Agricultural and Biological Engineering, Purdue University, Indiana, USA and International Institute of Tropical Agriculture (IITA), Nigeria.

\section{References}

Adom, K. K., Dzogbefia, V. P., \& Ellis, W. O. (1997). Combined effect of drying time slice thickness on solar drying of okra. Journal of the Science of Food Agriculture, 73, 315-320. https://doi.org/10.1002/(sici)1097-0010(199703)73:3\%3c315::aid-jsfa718\%3e3.0.co;2-n

Aguilera, J. M., \& Lillford, P. J. (1996). Microstructural and imaging analyses are related to food engineering. In Food Engineering 2000 (Eds. Fito P, Ortega-Rodriguez E, Barbosa-Canovas G.V). Chapman and Hall, N. Y. pp 23-38.

Alzamora, S. M., Gerschenson, L. N., Vidales, S. L., \& Nieto, A. (1996). Structural changes in the minimal processing of fruits: Some effect of blanching and sugar impregnation. In Food Engineering 2000 (Eds. Fito P, Ortega-Rodriguez E, Barbosa-Canovas G V). Chapman and Hall, N. Y. 117-139.

American Association of Cereal Chemists (2000). Approved Methods of the AACC, 11th ed. The Association: St. Paul, MN.

AOAC, 2000). Association of Official Analytical Chemists, AOAC International. Vol. 1. 18th ed. Arlington: VA, AOAC International.

Aryeetey, E. (2006). Ghana -Second Largest Importer of tin tomato. ISSER-Merchant Bank Development Seminar Series. Ghanaweb. Retrieved from http://ghanaweb.com/GhanaHomePage/NewsArchive/artikel.php?ID=1 Assessed 5th June, 2013 
Beecher, G. R. (1998). Nutrient content of tomatoes and tomato products. Proceedings of the Society for Experimental Biology and Medicine, 218(2), 98-100. https://doi.org/10.3181\%2F00379727-218-44282a

Chen, H., Hernandez, C. F., \& Huang, T. (2005). A study of the drying effect on lemon slices using a closed-type solar dryer. Solar Energy, 78(1), 97-103. https://doi.org/10.12777/ijse.8.1.69-74

Choi, S. Woo, H., Ko, S., \& Moon, T. (2008). Confocal laser scanning microscopy to investigate the effect of cooking and sodium bisulfite on in vitro digestibility of waxy sorghum flour. Cereal Chemistry, 85, 65-69. https://doi.org/10.1094/cchem-85-1-0065.

Davoodi, M. G., Vijayan, P., Kulkarnib, S. G., \& Ramana, K. V. R. (2007). Effect of different pre- treatments and dehydration methods on quality characteristics and storage stability of tomato powder. LWT Food Science Technology, 40, 1832-1840. https://doi.org/10.1016/j.lwt.2006.12.004

Doymaz, I. (2004b). Pre-treatment effect on sun drying of mulberry fruits (Morus alba L.). Journal of Food Engineering, 65, 205-209. https://doi.org/10.1016/j.jfoodeng.2004.01.016

Doymaz, I., \& Pala, M. (2002). Hot air drying characteristics of red pepper. Journal of Food Engineering, 55, 331-335. https://doi.org/10.21924/cst.2.2.2017.56

Dumoulin, E., \& Bimbenet, J. J. (1998a). Mechanical, Physical and Chemical Phenomena during Food Drying: Consequences on properties of dried products. In: Proceedings of Eleventh International Drying Symposium, August 19-22, Halkidiki, Greece, 711-718.

ECOM Canada Ingredients. (1997). Retrieved from http://ecomcanada.com/tomato.html

Falade, K. O., \& Omojola, B. S. (2010). Effect of Processing Methods on Physical, Chemical, Rheological, and Sensory Properties of Okra (Abelmoschus esculentus). Food Bioprocess Technology, 3, 387. https://doi.org/10.1007/s11947-008-0126-2.

Falade, K. O., Olufemi, T., \& Shogaolu, O. T. (2010). Effect of pre-treatments on air-drying pattern and color of dried pumpkin (Cucurbita maxima) slices. Journal of Food Process Engineering, 33, 1129-1147. https://doi.org/10.1111/j.1745-4530.2008.00330.x.

Gallali, Y. M., Abujnah, Y. S., \& Bannani, F. K. (2000). Preservation of fruits and vegetable using solar dryer: a comparative study of natural and solar drying III; chemical analysis and sensory evaluation data of dried samples (grapes, figs, tomatoes and onions). Renewable Energy, 12, 203-212. https://doi.org/10.1080/23311932.2018.1461731.

Gekas, V. C. (1992). Transport phenomena of foods and biological materials (Eds. Singh R.P, Heldman D.R). CRC Press, Boca Raton, FL.

Gogus, F., \& Maskan, M. (1999). Water adsorption and drying characteristics of okra (Hibiscus esculentus L.). Dry. Technol, 17, 883-894. https://doi.org/10.1080/07373939908917576.

Hawlader, M. N. A., Uddin, M. S. Ho, J. C., \& Teng, A. B. W. (1991). Drying characteristics of tomatoes. Journal of Food Engineering, 14, 259-268. http://www.nal.usda.gov/fnic/foodcomp/Data/car98/car98.html>. Assessed on $16^{\text {th }}$ March, 2017.

Jon, C. K., \& Kiang, C.S. (2008). Food dehydration and developing countries Food drying science and technology. In: Food drying science and technology, microbiological, chemistry applications. DEStech Publications Inc. Lancester Pensylvannia USA. pp 67-82.

Knockaert, G., Sudheer, K. P., Lemmens, L., Van Buggenhout, S., Hendrickx, M., \& Van Loey, A. (2012). Carrot B-carotene degradation and isomerization kinetics during thermal processing in the presence of oil. Journal of Agricultural and Food Chemistry, 60(41), 10312-10319. https://doi.org/10.1021/jf3025776.

Krokida, M. K., Karanthanos, V. T., \& Maroulis, Z. B. (2000). Effect of osmotic dehydration on color and sorption characteristics of maple and banana. Drying Technology, 18, 937-950.

Latapi G., \& Barrett, D. M. (2006). Influence of pre-drying treatments on quality and safety of sun-dried tomatoes. Part I: Use of steam blanching, boiling brine blanching and dips in salt or sodium metabisulfite. Journal of Food Science, 71, 1-20. https://doi.org/10.1111/j.1365-2621.2006.tb12401.

Lenart, A. (1996). Osmo-convective drying of fruit and vegetable tissues undergoing osmotic processing. Drying Technology, 14, 2-10. https://doi.org/10.1080/07373939608917104.

Lin, T. M., Durance, T. D., \& Scaman, C. H. (1998). Characterization of vacuum microwave, air and freeze dried carrot slices. Food Research International, 4,111-117. https://doi.org/10.1016/S0963-9969(98)00070-2. 
Owureku-Asare, M., Agyei-Amponsah, J., Saalia, F. K., Alfaro, L., Espinoza, L., \& Sathivel, S. (2014). Effect of pre-treatment on physicochemical quality characteristics of a dried tomato (Lycopersicon esculentum). African. Journal of Food Science, 8, 253-259. https://doi.org/ 10.5897/ajfs2014.1156

Papaioannou, E. H., \& Karabelas, A. J. (2012). Lycopene recovery from tomato peel under mild conditions assisted by enzymatic pre-treatment and non-ionic surfactants. Acta Biochimica Polonica, 59, 71-74.

Periago, M. J., \& Garcia-Alonso, J. (2009). Bioactive compounds, folates and antioxidant properties of tomatoes (Lycopersicum esculentum) during vine ripening. International Journal of Food Sciences and Nutrition, 60(8), 694-708. https://doi.org/10.3109/09637480701833457.

Piga, A., Pinna, I., Ozer, K. B., Agabbio, M., \& Aksoy, U. (2004). Hot air dehydration of figs (Ficus carica L.): drying kinetics and quality loss. International Journal of Food Science and Technology, 39, 793-799. https://doi.org/10.1111/j.1365-2621.2004.00845.

Pizzocaro, F., Torregiani, D., \& Gilardi, G. (1993). Inhibition of apple Polyphenoloxidase (PPO) by ascorbic acid, citric acid and sodium chloride. Journal of Food Processing and preservation, 17, 21-30. https://doi.org/10.1111/j.1745-4549.1993.tb00223.

Prabhakar, K., \& Venkateswara, S. (2014). Dried Foods. Encyclopedia of Food Microbiology, 1, 530-537.

Prothon, F., Ahrne, L. M., Funebo, T., Kidman, S., Langton, M., \& Sjoholm, I. (2001). Effect of combined osmotic and microwave dehydration of apple on texture, microstructure and rehydration characteristics. Lebensm Wiss Technology, 34, 95-101. https://doi.org/10.1006/fstl.2000.0745.

Rajkumar, P., Kulanthaisami, S., Raghavan, G. S. V., Garie'py, Y., \& Orsat, V. (2007). Drying kinetics of tomato slices in vacuum assisted solar and open sun drying methods. Drying Technology, 25, 1349-1357. https://doi.org/10.1080/07373930701438931.

Ranganna, K. (1986). Handbook of analysis and quality control for fruits and vegetable products. New Delhi: Central Food Technological Research Institute, Mysore. Tata McGraw-Hill Pub. Co.

Sargent, J. A. (1988). Low temperature scanning electron microscopy: Advantages and application. Scanning Microscopy, 2, 835-849. http://digitalcommons.usu.edu/foodmicrostructure/vol7/iss2/2.

Singh, R., Mangaraj, S., \& Kulkarni, S. D. (2006). Particle-size analysis of tomato powder. Journal of Food Processing and Preservation, 30, 98. https://doi.org/10.1111/j.1745-4549.2005.00050.

Stahl, W., \& Sies, H. (1996). Lycopene: a biologically important carotenoid for humans? Archives of Biochemistry and Biophysics, 336, 1-9.

Tonucci, L., Holten, J. M., Beecher, G. R, Kachik, F., Davis, C. S., \& Mulokozi, G. (1995). Carotenoid content of thermally processed tomato based food products. Journal of Agricultural Food Chemistry, 55, 1597-1603.

Tortoe, C., \& Orchard, J. (2006). Microstructural changes of osmotically dehydrated tissues of apple, banana and potato. Scanning, 28, 172-178. https://doi.org/10.1002/sca.4950280306.

Verma, A., Dikshit, S. N., Panigrahi, H. K., \& Pandey, N. (2016). Study of physico-chemical composition of fresh tomato and standardization of recipe for tomato juice. National Academy of Agricultural Science, 34, 4. https://doi.org/10.1080/23311932.2017.1310596.

Wang, N., \& Brennen, J. G. (1991). Moisture sorption isotherm characteristics of potatoes at four temperatures. Journal of Food Engineering, 14, 269-287. https://doi.org/10.1016/0260-8774(91)90018-N.

Zogzas, N. P., Maroulis, Z. B., \& Marinos-Kouris, D. (1994). Densities, shrinkages and porosity of some vegetables during hot-air drying. Drying Technology, 12, 1653-1666. https://doi.org/10.1080/07373937.2015.1036289.

\section{Copyrights}

Copyright for this article is retained by the author(s), with first publication rights granted to the journal.

This is an open-access article distributed under the terms and conditions of the Creative Commons Attribution license (http://creativecommons.org/licenses/by/4.0/). 